\title{
THE CONCEPTION OF THE FATHERLAND DISHONORED BY CAPTIVITY IN THE UKRAINIAN POETIC HISTORY AND PHILOSOPHY
}

\author{
ROMAN GOLOD
}

\begin{abstract}
In the article, an analysis of the conception of the Fatherland dishonored by the captive colonial status is provided with regard to the artistic work of the Ukrainian poets. The feeling of shame, rage and hatred towards the enslaved Ukraine is more or less seen in the historic and philosophic views of T. Shevchenko, P. Kulish, I. Franko, L. Ukrainka, I. Malaniuk. The prominent poets have always been playing the role of 'nerves', indicators of the political, social, cultural and moral health of the people. So the conception of shame for the captivated Ukraine in their artistic work should be viewed as the determinant for the further nation recovery.
\end{abstract}

Keywords: history and philosophy, poetry, Ukrainian literary tradition, the image of the captivated Ukraine, psychic and emotional prominency.

How to tread the trails that lead to You?

In the haze of gray distinguish goal?

Will the Europe's flame that 's burning blue

Burn the Asian leprosy of gold?* -Yevhen Malaniuk wrote this in his poetry called The Homeland in 1931 , and it seems as if he could see from his historic time into our reality.

Unfortunately, we have not overcome 'the Asian leprosy of gold' in our Homeland, despite gaining Independence, despite building our own State and despite the fact that the 'blue flame of Europe' is warming the soul of every Ukrainian patriot. The feeling of shame for the elite's 'leprosy of gold' and for the loyal profanum vulgus has, to some extent, been felt by every self-conscious citizen. The artists, who are the nerves of a nation, open to all of the hurt and injustice of social life, feel this shame in the deepest and most painful way.

This shame in Ukrainian literary tradition has always been relevant, and throughout ages it has morphed into a constant concept. Taras Shevchenko felt it in his time, turning his painful feelings into an angry invective against the national 'elites' ('Toadies, slaves, the filth of Moscow, / Warsaw's garbage-are your lords,/ Illustrious hetmans! Why so proud/And swaggering, then do you boast, you/ Sons of Ukraine and her misfortune?/ That well you know to wear the yoke,/More than your fathers did of yore?' [8, p. 351-352]); as well as to the ordinary people ('...People, people! For a piece of rotten sausage, you will sell your mother.' [9, p. 97]). According to D. Dontsov: 'his condition inflicted on Ukraine by the alien yoke and by her own Kochubejs, the condition of the "blinded and deafened"; the condition of not caring for the community; the condition causing him [Shevchenko] despair; the

\footnotetext{
${ }^{*}$ From here and on translations of the poetic texts are provided by O. Zagorodnyuk unless otherwise is stated
} 
condition in which he felt in his own magnificent land was a desert, this condition of Ukraine took him to "the many-peopled cross-roads" together with his thunderous word, which shook, reprimanded, and reminded the "deaf and mute kind", as prophets of old would have said, calling them to "wake up", "to become people", to renew, to resurrect in themselves the old spirit of Cossacks, to tear down the bonds of thralldom, and to become free, watering the freedom with the foe's blood.' [2, p. 49-50].

In 1895 Lesia Ukrainka in her letter to Mykhailo Pavlyk wrote: 'The shame and the bitterness for my country are just gnawing at me (that's not just an expression, trust me), I wouldn't have thought that my soul had such a reserve of fury. I don't even know what I am going to do after I return to Russia, the mere thought of that prison life makes my heart sink. I don't know about others, but I just can't silently bear that life under the yoke.' [5, p. 297].

Leading Ukrainian poets and citizens perceived the shame of a freedomless, stateless nation as a personal disgrace. Therefore something negative about their nation they proclaimed as did Something about Myself by Ivan Franko: 'First of all, I will admit to the sin, which a lot of the patriots consider to be my deadly sin: I do not like Ruthenians. In comparison with the flames of love towards the "brotherly tribe" that spring so frequently from the pages of Polish reactionary newspapers my confession may appear odd. Yet what can I do about it when it is the truth? I am not of the age of a naive and blind lover anymore, so I can soberly discuss such a delicate matter as love. Therefore, I repeat: I do not love Ruthenians. There are so few real characters among them, yet there is so much pettiness, narrow egoism, double-mindedness and conceit, that I really do not know what I would love them for, even despite those bigger and smaller pins that they, with the best of the intentions, have pushed under my skin.' [10, vol. 31, 30]. It probably was not easy for Ivan Franko to admit the following as well: 'I confess to an even greater sin: I do not love our Rus' in the way and to the extent that patented patriots do or pretend to do. What is there to love? To love her as a geographical concept, I am too great an enemy of such empty phrases, and I have seen too much of the world to assure that there is nowhere such beautiful nature as in Rus'. I know her history too well to love her for it, and I love the universal ideals of justice, fraternity, and freedom too much not to feel how few examples of true civil spirit, true selfsacrifice, and true love exist in the history of Rus'. No, it is very hard to love this history, because almost every step of it calls for tears rather than love. Or maybe I should love Rus' as a race - this heavy, awkward, sentimental, devoid of hardiness and willpower race, with so little ability to manage the political life within its own trash-heap, yet so fruitful with turnskins of the most diverse variety? Or maybe I am to love the bright future of that Rus', when I do not know that future, and I see no basis for it to be bright?' [10, vol. 31, 31]. And when, despite numerous disappointments and temporary despair, the writer still himself identifies as Rusyn, 'not for reasons of sentimental nature', but from the 'sense of a dog's duty'. 'My Rus' patriotism', Franko notes, 'is no sentiment, no national pride, but a heavy yoke imposed on my shoulders. I can shudder, I can quietly curse the fate that laid the yoke on my shoulders, but I cannot throw it away, I cannot look for another homeland, because I would be reprehensible to my own conscience. And if something lightens this yoke to me, it is seeing the people of Rus', who, though they have been oppressed, kept in the dark and demoralized for many centuries, and today are poor, ill-fated and helpless, still slowly rise, with ever wider masses starting to feel the thirst for light, truth and justice, and seeking ways to get there. Therefore, it is worth working for this people and no work will go to waste.' [10, vol. 31, 31].

Franko's national self-criticism was never frivolous or renegade, it was self-criticism for selfperfection, it was a hatred caused by greater love, it was a classic version of odi et amo. Apart from the shortcomings in the progress of his own people, the writer did not lose sight of positive shifts. To the well-known invective of $\mathrm{P}$. Kulish - 'A people without sense, without honor and respect, / Without truth in the covenants of the savage ancestors, / You, who came from an insane courage / Bitter drunks and robbers great!' - Franko replies: 'Tell me yourselves, is it possible to talk in such a way about the people, who, whatever their sins may be - and any nation, like every man, has sins (And who knows if some are not bigger than ours?) - wrote the history of their struggle for freedom with their blood and bones, and. in the most difficult era of Tatar invasions and great ruin, did not lose the thought of freedom; about the people who have brought up a scholar amongst themselves today, who in his 
revelations, songs, and tales, built such a lasting monument of his healthy, intelligent, and honest thoughts, with his commitment to light and justice; about a people who, despite long-term oppression and destruction, did not lose their national identity and their sense of human dignity, and did not worship any of the triumphant tyrants?' [10, vol. 26, 166].

It is characteristic that the poet speaks in the defense of the people, despite his rhetoric not straying farm from Kulish's invectives in the famous Prologue to Moses:

My people, tortured utterly and shattered,

Like a poor cripple at the cross-roads lying,

By man's contempt, as if with scabs, bespattered!

My soul is filled for you with care and sighing,

And burning shame permits my sleeping never,

To see the fate before your children lying!* $[10$, vol. 5, 212]

Franko, just like Kulish, sometimes falls into despair, because he is aware of the difficulties and dangers he, along with the people, must overcome on their way to the promised land. He confesses his weakness himself: 'But, care-burdened and impeded, / Torn by sad doubts, and crushed beneath repining, /Not for us to the battle line to speed you!"* [10, vol. 5, 214]. However, just like the biblical Moses, Franko ultimately rejects the doubts and relies on the belief that:

... the time will come and, radiant shining,

You'll shake the Caucasus; one of the free nations,

With the Carpathians as your girdle twining.

You'll set the mighty sound of freedom racing

Over the Black Sea, free-holder, well-seated,

In your own house, in your own fields' broad spaces!

Accept this song, grief-swaddled, I entreat you,

Yet full of faith, bitter yet free, though sorrow's

Tears wash it, it is earnest of what will meet you,

My humble bridal gift for your tomorrow! * [10, vol. 5, 214]

Franko's seminal epic poem appears to be filled with faith, not despair, since through faith, as Vasyl Ivanishin correctly pointed out, 'every human being and the whole nation have the opportunity to draw from the eternally living source of power as much as their soul is able to receive.' [3, p. 599-600].

Actually, Franko's faith in his people, emerging from the experience of shame for their abusive status was passed down to the future generations of Ukrainian poets. Here is how close to that of Kameniar's is the vision of the future of the Ukrainian people in the writings by Yevhen Malaniuk:

Rejoice, my enemy, in vain,

Nor lyrist, neither paralyzed

My kin`s. In action`s hurricane

By him you, heathen, will be cast.

You will unfortunately send

Moscow`s ambassadors to Kyiv

And our hall parquet will seem

So slippery for steps so frail [6, p. 12]

\footnotetext{
* Translated by Vera Rich, http://sites.utoronto.ca/elul/English/Franko/Franko-Moses.pdf
} 
Ideological connection of a series of Franko's poems with Malaniuk's cycles Antimaria or Steppe Ellada is pointed out by an academic Taras Saliga in his article with the title Semper Tiro from Franko's Academy of Sciences: "From the poet's "excessive love" of the Rusyns, of the Steppe Hellas, and of Ukraine, the antithetical images were created: "Sinking sludge," "patented patriots," "playground of intentions," "hapless kind," "troubled ant colony" in Franko, and in Malaniuk - "prostitutes of khans and kings," "harlotry on the crossroad," "Pris'ka of Peter, the Hetman," "Shameless mother of janissaries," "people who have dissolved the evil in vodka," "white-skinned commodity," etc.' Such 'antitheses,' according to the researcher, in cases of both Franko and Malaniuk, 'were the last artistic injections for national healing, for the awakening of national consciousness.' [7, p. 222-223]. The opinion is undoubtedly correct, although apparently it is rebuked by Malaniuk himself, who was convinced that "self-identification as a "Little Russia" is our historical illness, the many-years-old disease, hence it is chronic. No temporal injections, nor even surgery will help here. It will have fought for many decades.' [4].

Unlike Ivan Franko, who believed that he had approached the promised land, Malaniuk, in his own cultural and historical situation, realized that with each new decade of Ukrainian descent, a free and independent homeland, like Fata Morgana, was increasingly fading away from him not only geographically, but also mentally:

As hard as death is now your prison

The foul malodor of murk.

How can you even still be dreaming

of the great freedom of the past? [6, p. 40]

So it is only natural that Malaniuk's injection for a chronic Ukrainian statelessness should have had a much higher dose than Franko's medicine. Cruelly and unambiguously, the poet reminds his readers of shame ('Here the whole body is being burned by shame, / more acute than the pain of any punishment/ When with the lecherous gaze / The master is looking at you naked') regarding the one whom Shevchenko believed to be robbed and lulled to sleep by evil people, yet still a mother:

No, you are not a Mother. In state of lover's fervor

With the black flame of braided hair

In the face of the steppe captive

The intoxication of Cuman beauty [6, p. 40]

The ruthless judgment of the poet in the Motherland is pronounced in the poem Antimaria:

But an ill-fated incarnation

You're neither Sophia, nor Mary

Green gaze of serpent has betrayed

In you the wicked witch and harlot [6, p. 55]

Malaniuk's Ukraine appears in the form of 'lustful Scythian hetaira' in the cycle From Wormwood:

Underneath you the brocade carpet of wheat

Above you the satin of blue skies

Yet you, mad harlot, covered in scratches

and in wild saliva of lovers, the corruption of beauty! [6, p. 18]

Analyzing the philosophy of these lines of Malaniuk, Yuri Sherekh wrote that it was 'an intense search for the forces that could turn Ukraine back to the path that the poet wanted her to follow. The utopia of the Steppe Hellas ends with the curse for this country of the Sarmatian Aphrodite and the snub-nosed Apollonians. The concept of iron Rome, the concept of Varangian steel, was developed. The 
image of the poet is developed - not just a poet (since being a poet is painfully insufficient), but of an invincible, proud emperor of iron stanzas, who sounds a salute to the future' [6, p. 19].

Although the collective image of the enslaved Ukraine in the work of E. Malaniuk is much tougher, even somewhat provocative, because of the elements of naturalistic poetics, yet the figurative and symbolic essence of his poetry is evidently drawn from Shevchenko's style:

The Ruin. The Ruin. Like fate or judgement

As generations unwind - forever, till time's end

Without a meaning, without a measure

On this three times cursed, this punished land [6, p. 67]

Other researchers, including Volodymyr Bazylevsky and Ivan Dzyuba, also paid attention to the general similarity of Malaniuk's shame motif for the enslaved Motherland with Ukrainian literary tradition. The latter, for example, says: 'That, which in Shevchenko's case, has, say, a socially selective, socially oriented character ('Slaves, the footstools, dirt of Moscow, / your lords are the Warsaw garbage, / the noble hetmans'); in Panteleimon Kulish ('A senseless people, with no honor, nor respect ...'), Lesia Ukrainka ('Our people, like a child, born blind, / have given over to hangman all their guides'), and Ivan Franko ('He's like a paralytic sitting on a cross-road...') it was a 'situational' motive in the dramatic art of thought - in Malaniuk's works it becomes the leitmotif, the main nerve of his poetry, although, of course, this nerve resonates to all the signals of life, and resonates sometimes with wounded voice.' [1, p. 793-794]. The researcher agrees with the opinion of Volodymyr Bazylevsky, who says 'In his unappeasable reprimand of the apostasy and self-identification as a "Little Russia", Malaniuk sometimes, contrary to himself, sees it as phenomena of a personalized moral character, whereas this apostasy is only one manifestation of a historically underdeveloped national society, the lack of national self, and 'blasphemous poems' of Malaniuk, the fierce damnation of 'Steppe Hellas', Ukraine - 'harlotry', 'prostitute of khans and kings' (even fired with the same fierce love) - are not completely adequate to the real historical factors.' [1, p. 794].

The above statement is the key, in our opinion, not only to interpreting Yevhen Malaniuk's works, but also in general to have the conversation on the topic of 'the concept of shame for the enslaved Motherland in the Ukrainian literary tradition.' The 'shame' of all the great poets mentioned above is precisely 'fired with fierce love.' After all, the shame for the homeland, for the people, for the nation neither for Shevchenko, nor for Kulish, Lesya, and Franko, nor even for Malaniuk himself was an end in itself. And, least of all, this 'shame' can testify to the Ukrainian inferiority complex. This psychoemotional significance becomes clear only as when considered as an element functioning in triune integrity of emotional nervous reactions - love, shame, and rage. It is these components, assembled in a single injection, that can provide not only immune support for the formation of a young Ukrainian European state, but also become a good preventive tool against chronic ailments, including those of Asian (Byzantine) origin, among which the 'leprosy of gold' might just be the most dangerous contemporary ailment.

\section{REFERENCES}

[1] Дзюба І. М. 3 криниці літ: у 3 m., Т. 1. Києво-Могидянська академія, Київ, 2006. [Dziuba I. M. Z krynytsi lit: u 3 t., T. 1. Kyievo-Mohylianska akademiia, Kyiv, 2006.]

[2] Донцов Д. Незримі скрижалі Кобзаря (Містика хицарства запорозького). Гомін України, Торонто, 1961.

[Dontsov D. Nezrymi skryzhali Kobzaria (Mistyka lytsarstva zaporozkoho). Homin Ukrainy, Toronto, 1961.]

[3] Іванишин В. Державність нації: збірка працьь, Т. 1. Астон, Тернопіль, 2009.

[Ivanyshyn V. Derzhavnist natsii: zbirka prats, T. 1. Aston, Ternopil, 2009.] 
[4] Клочек Г. До істинного Тараса Шевченка. Аітературна Україна, 17 травня (2001).

[Klochek H. Do istynnoho Tarasa Shevchenka. Literaturna Ukraina, 17 travnia (2001).]

[5] Українка А. Зібрання творів у 12 m., Т. 10. Наукова думка, Київ, 1978.

[Ukrainka L. Zibrannia tvoriv u 12 t., T. 10. Naukova dumka, Kyiv, 1978.]

[6] Празька поетична икола. Антологія. Упоряд. текстів та передм. Астаф'єва О.Г., Дністрового А.О. Веста, Ранок, Харків, 2004.

[Prazka poetychna shkola. Antolohiia. Uporiad. tekstiv ta peredm. Astafieva O.H., Dnistrovoho A.O. Vesta, Ranok, Kharkiv, 2004.]

[7] Салига Т. 'Semper tiro' з Франкової “академії наук”. В: Салига Т. Воздвиження храму. Світ, Аьвів, 2008.

[Salyha T. 'Semper tiro' z Frankovoi "akademii nauk". V: Salyha T. Vozdvyzhennia khramu. Svit, Lviv, 2008.]

[8] Шевченко Т. Зібрання творів: У 6 m. Т. 1: Поезія 1837-1847. Київ, 2003.

[Shevchenko T. Zibrannia tvoriv: U 6 t. T. 1: Poeziia 1837-1847. Kyiv, 2003.]

[9] Шевченко Т. Зібрання творів: У 6 m. Т. 2: Поезія 1847-1861. Київ, 2003.

[Shevchenko T. Zibrannia tvoriv: U 6 t. T. 2: Poeziia 1847-1861. Kyiv, 2003.]

[10] Франко I. Зібр. творів: У 50 m. Наукова Думка, Київ, 1978 - 1986.

[Franko I. Zibr. tvoriv: U 50 t. Naukova Dumka, Kyiv, 1978 - 1986.]

Address: Roman Golod, Vasyl Stefanyk Precarpathian National University, 57, Shevchenko Str., IvanoFrankivsk, 76025, Ukraine.

E-mail: rom2635@bigmir.net

Received: 29.06.2018; revised: 03.12.2018.

Голод Роман. Концепція зганьбленої неволею Вітчизни в українській поетичній історіософії. Журнал Прикарпатського університету імені Василя Стефаника, 6 (2) (2019), 86-91.

У статті здійснено аналіз концепції зганьбленої підневільним колоніальним статусом Вітчизни у творчості провідних українських поетів. Відчуття сорому, люті і навіть ненависті до поневоленої України більшою чи меншою мірою притаманні історіософським поглядам Т. Шевченка, П. Куліша, I. Франка, Лесі Українки, Є. Маланюка. Визначні поети завжди виконують роль “нервів", індикаторів політичного, соціального, культурного, морального здоров'я народу. Тож концепцію сорому за поневолену Україну у їхній творчості слід розгдядати і як детермінанту подальшого оздоровлення нації.

Кдючові слова: історіософія, поезія, українська літературна традиція, образ поневоленої України, психо-емоційна значущість. 